\title{
Kariyer Planlama ve Geliştirme Uygulamalarma İliş̧kin Bir Özel Hastanede Çalışan Hemşirelerin Görüşleri
}

\author{
Ebru SEVINÇ*, Necmiye SABUNCU**
}

\section{$\ddot{\mathbf{O z}}$}

Amaç: Bu çalışma, özel sektörde hizmet veren bir hastanedeki kariyer planlama ve geliştirme uygulamaları ile bu kurumda çalışan hemşirelerin kariyer planlama ve geliştirmeye ilişkin görüşlerinin belirlenmesi amacıyla planlanmıştır.

Yöntem: Araştırma tanımlayıcı bir araştırma olup, İstanbul ilinde bulunan özel bir hastanenin Avrupa ve Anadolu yakasında ki şubelerinde Aralık 2008 - Şubat 2009 tarihleri arasında 237 hemşire üzerinde gerçekleştirilmiştir. Araştırmanın verileri, araştırmacı tarafından literatür doğrultusunda hazırlanan ve toplam 30 maddeden oluşan anket formu ile toplanmış, verilerin analizi SPSS paket programında yapılmıştır.

Bulgular: Elde edilen bulgulara göre; hemşirelerin \%50.2'si kurumlarında kariyer planlama ve geliştirme uygulamasının olmadığını, \%40.9'u kurumlarındaki açık pozisyonlar için bilgilendirme yapılmadığını, \%67.1’i üst pozisyona getirilmelerinde yetenek ve performansın dikkate alındığını, \%48.1’i kurumlarında ve hemşirelik hizmetlerinde kariyer planlama ve geliştirmeye yönelik uygulamalardan kurs ve seminerlere katılımın sağlandığını belirtmişlerdir. Hemşirelerin kariyer planlama ve geliştirme ile ilgili kurumlarından beklentileri arasında \%58.2'si sürekli eğitim programlarının düzenlenmesini ifade ederken, \%56.1'i kariyer planlama ve geliştirmenin hemşirelik mesleğine katkı sağlayacağını belirtmişlerdir.

Hemşirelerin kurumdaki kariyer faaliyetleri ile pozisyon, yaş, eğitim durumu, toplam çalışma süresi, kurumdaki çalışma süresi ve aynı pozisyonda çalışma süreleri arasında istatistiksel olarak anlamlı farklılıklar saptanmıştır ( $\mathrm{p}<0.05)$.

\footnotetext{
Özgün Araştırma Makalesi (Original Research Article)

Gelis / Received: 22.10.2018 \& Kabul / Accepted: 22.11.2018

* Öğ.Gör., İstanbul Gelişim Üniversitesi, Sağllk Bilimleri Yüksekokulu, İstanbul, Türkiye, E-posta: esevinc@gelisim.edu.tr, ORCID ID https://orcid.org/oooo-0003-3553-5825

*** Prof.Dr., Haliç Üniversitesi, Hemşirelik Yüksekokulu, İstanbul, Türkiye, E-posta: necmiyesabuncu@halic.edu.tr, ORCID ID https://orcid.org/o000-0003-0643-9922
} 
Sonuç: Çalışmada, kurumda çalışanlara yönelik kariyer planlama ve geliştirme politikasının olmadığı, kariyer planlama ve geliştirmeye yönelik uygulamaların ise yetersiz olduğu sonucuna ulaşılmıştır.

Anahtar Sözcükler: Hemşirelik, kariyer danışmanlığı, özel hastaneler.

\title{
The Opinions Related to Career Planning and Developing Applications of the Nurses who Works at a Private Hospital
}

\begin{abstract}
Aim: This study was planned to determine career planning and development practices in a private hospital and the views of nurses working in this institution.

Method: The research was a descriptive study and was conducted on 237 nurses from December 2008 to February 2009 in the European and Anatolian side of a private hospital in Istanbul. The data of the study were collected by the researcher in the form of a questionnaire consisting of a total of 30 items prepared in the light of the literature and the analysis of the data was made in the SPSS package program.
\end{abstract}

Findings: According to the findings; $50.2 \%$ of the nurses stated that there is no career planning and development practice in their institutions, $40.9 \%$ of them that they were not informed about open positions in their institutions. $67.1 \%$ of them that they were considered of the ability and performance to be brought to the upper position and $48.1 \%$ of them that participation in courses and seminars were provided for their career planning and development practices in their institutions and nursing services. While $58.2 \%$ of the nurses' expectation from career planning and development institutions stated that they would organize continuous education programs, $56.1 \%$ stated that career planning and development would contribute to the nursing profession.

It was determined statistically significant differences between career activities of the nurses at instituon, position, age, education situation, total working time, total working time at instution, working time at the equal positions $(\mathrm{p}<0.05)$.

Conclusion: In the study, it was concluded that there is no career planning and development policy for the employees in the institution and the practices for career planning and development are insufficient.

Keywords: Nursing, career counseling, private hospitals. 


\section{Giriș}

Bireyin iş yaşamındaki yükselen başarısı ile birlikte iş hayatındaki eylem, tutum ve davranışlarını kapsayan, böylece kendilerine daha fazla güç, statü ve gelir sağlayan süreç olarak kariyer; bireyin sorumluluğunda şekillenen, örgüt tarafından desteklenen bir olgudur ${ }^{1}$.

Kariyer kavramı; yalnızca üst düzey pozisyonları işgal edenlerin ilerleme olanağı değil, kurumdaki tüm çalışanların çalışma yaşamında ilerlemesini kapsamaktadır. Kariyer planlaması, kişisel yeteneklerin gelecekte kullanılması sürecidir. Kariyer planlamasının en temel amaçlarından biri, bireylerin sahip oldukları birikim ile geleceklerini kontrol edebilme yeteneklerinin geliştirilebilmesini sağlamaktır ${ }^{1,2}$.

Kurumlar; çalışanlarının daha üretken olabilmesi, yaratıcılıklarının geliştirilmesi, verimliliklerinin arttırılması ve ekonomik gelişmelere ayak uydurabilecek bilgi ve beceriye sahip olmalarını sağlayabilmek için etkin bir kariyer planlamaya ihtiyaç duymaktadır. Bu nedenle, çalışanların bireysel ve mesleki yeteneklerini ortaya çıkarma ve geliştirmenin yanı sıra, çalışanların kurumdan beklentilerini karşılama, yüksek performansa sahip, nitelikli çalışanların kurumda kalıcılığını sağlamak gibi örgütsel amaçları doğrultuşunda bireysel ve örgütsel kariyer gelişimi ve yönetimine önem vermekte, birey-örgüt bütünleşmesini sağlamak amacı ile örgütsel kariyer sistemleri geliştirmektedir ${ }^{1,3}$.

Geleceğin kurumlarının kendini yöneten, motive eden, kariyerini yönlendiren ve geliştiren uzman çalışanlarla başarılı olacağı düşünülmektedir. Teknolojik gelişmeler, yeni iş görme yöntemleri, iş öğeleri, beceriler ile istihdamda fırsat eşitliği konusundaki toplumsal baskılar ve bireyin kariyer yönetiminde daha fazla söz sahibi olma yönündeki örgüt içi baskılar kariyer geliştirme programlarının önemini arttırmaktadır4.

Bireysel kariyer gelişimi, bireyin kendi kariyerini planlaması ve bu planların eğitim, öğretim, iş arama ve iş deneyimleri vasıtasıyla yerine getirilmesi ve yürütülmesidir. Bireylerin daha geniş istihdam olanakları sağlayabilmeleri için kariyer geliştirme ve planlamada öncelikle bireysel sorumluluk almaları önemlidir. Kariyer yolu, bireyin kişisel amaçlarına ulaşmak için geçtiği yollar olarak tanımlanmaktadır. Organizasyonların bu konudaki sorumluluğu, kariyer yollarında yükselişin yöntem ve 
sistematiğinin nasıl olacağını belirlemek, ilke ve işlemlerin neler olduğunu açıklamaktır ${ }^{1,2,5,6}$.

Örgütsel kariyer planlama, örgütsel amaçlara ulaşmak için bireysel kariyer planlamanın sürdürülmesi ve yönetilmesi olarak da değerlendirilmektedir. Kariyer planlamanın örgüte sağladığı yararlar arasında, adaletli ve nesnel işe alma, seçme ve yerleştirme politikaları ile eşit iş fırsatı sağlama, personel değerlendirmede nesnel bir ölçüt sağlama, performans değerleme yöntemi ile eşit iş görenlere eşit ücret ödenmesini olanaklı kılma yer almaktadırı,6.

Kariyer danışmanlığı, kariyer geliştirmede önemli bir fonksiyondur. Danışmanlar genelde, görüşme ve aldıkları bilgi yoluyla bireylerin ihtiyaçlarını keşfetmelerine yardımcı olmaktadır. Bireyler, kariyer danışmanları aracılığıyla güçlü ve zayıf yönlerini belirlemede sadece bireysel algılamalarını değil, aynı zamanda örgütü algılamalarını da ortaya çıkarmaktadır. Kariyer danışmanı, bireyin kendini analiz etmesi, mesleği ve kariyeri hakkında bilgi edinmesi ve bunlar arasındaki uyumun sağlanmasında rol almaktadır 2,7 .

Türkiye'de sağlık hizmetleri, geçmişten günümüze devletin kontrolünde yürütülmüş olmakla birlikte, son yıllarda özel sağlık kuruluşlarının sağlık sektörüne girmesiyle sektörde özel sermayenin arttı̆̆ görülmektedir. Ancak özel sektöre ait hastanelerde örgütlenme ve uygulamalar yasal faktörlerin etkisi ile kamuya ait hastanelerden farklı olmamış, daha çok hasta memnuniyetinin sağlanması ve kurumsal kâra odaklanılmıştır. Ancak; nitelikli iş gören ihtiyacı, iş gören devir hızıyla baş edebilme, insan kaynakları maliyetini azaltma gibi faktörler insan kaynakları uygulamalarının önemini arttırmış ve özel sektöre ait hastanelerde insan kaynakları departmanları aktif hale getirilmiştir3,8,9.

Hastanelerde hemşireler, iş gücünün büyük bir kısmını oluşturmakta ve hastanelerin misyon ve vizyonu doğrultusunda örgütsel hedeflerin gerçekleştirilmesinde önemli rol oynamaktadır. Sağlık alanındaki değişimler ve oluşan gereksinimler nedeniyle sağlık kuruluşları, nitelikli hemşire ihtiyacını, hemşirelerin bireysel ve mesleki gelişimlerinin sağlanması ile giderebilmektedir3,10,11.

Kariyer planlama hemşirelerin çalışma hayatındaki performanslarını ve başarılarını olumlu yönde etkileyerek, onlar için gerekli olan bilgi beceri ve davranışlar 
geliştirmeleri, profesyonel olarak ilerlemelerinde, iş ve özel yaşamında oluşan değişikliklere uyum sağlamalarında önemli bir araçtır ${ }^{12}$.

Hemşirelikte kariyer planlama ve geliştirmede, kurumlar tarafından kullanılan tekniklerden biri olan kariyer planlama ve geliştirme atölyeleri genel olarak katılımcıların bireysel kariyerlerini gözden geçirme, bireysel güçlü ve zayıf yönleri ile kariyer tercihlerini belirleme, bireysel ve mesleki destek kaynaklarını tanımlama ve nasıl kullanılacağını belirleme, sağlık sektöründeki uygun iş fırsatlarını değerlendirme ve bireysel pazarlamayı öğrenme amacıyla uygulanmaktadır. Hemşirelikte kariyer geliştirme sistemi, hemşirelik bakımında kalitenin, hemşirelikte ve çalışma koşullarında mükemmellik ile iş doyumunu gelişimini ve öz değerin artmasını sağlamaktadır5,6.

6283 sayılı Hemşirelik Kanunu'na göre Türkiye'de hemşirelik ile ilgili lisans eğitimi veren fakülte ve yüksekokullardan mezun olan ve diplomaları Sağlık Bakanlı̆̆ı'nca tescil edilenlere hemşire unvanı verilmektedir ve hemşirelikte cinsiyet ayrımı kaldırılarak Türkiye Cumhuriyeti vatandaşı olma koşulu getirilmiştir (Madde 1;3). Ayrıca meslekleri ile ilgili alanlarda lisansüstü eğitim programlarından mezun olan hemşireler, uzman hemşire olarak çalışabilme hakkına ve bununla birlikte özel birim ve alanlarda çalışan hemşireler ise Sağlık Bakanlı̆̆ı'nca çıkartılacak yönetmeliklerle belirlenecek esaslar dâhilinde ilgili alanlarda yetki belgesine sahiptir (Madde 8). Hemşirelik ile ilgili yönetim görevlerinde daha önce lisans mezunlarına verilen öncelik (rüçhan) hakkı ise lisans ve lisansüstü hemşireler olarak genişletilmiştir (Madde 9). Böylece hemşirenin görevlerini ve hemşire unvanına sahip olma gibi hemşirelik mesleği için en temel konuların güncelleştirilmesi sağlanmıştır ${ }^{10}$. Hemşirelik Kanunu'nun değiştirilen maddelerinin uzmanlaşma ve branşlaşma ile ilgili hükümleri ve hemşirelikte yönetim pozisyonlarına lisans ve lisansüstü hemşirelere öncelik hakkı tanıması hemşirelikte kariyer planlama ve kariyer geliştirme uygulamalarını etkileyebilecek olumlu bir gelişme olarak değerlendirilebilmektedir ${ }^{8}$.

Sağlık Bakanlığı Hizmet İçi Eğitim Yönetmeliğine göre, eğitimler oryantasyon eğitimi, iş başında eğitim, kurs ve semineler, toplantılar, inceleme gezileri, doktora, uzmanlık eğitimi ve diğer kurum ve kuruluşlarda eğitime katılma vb. şeklinde yapılmaktadır7.

Sağlık Bakanlı̆̆ı, son yıllarda sağlık sektöründe yaşanan değişimlerden etkilenerek, yeni vizyonu çerçevesinde; idari ve mali özerkliğe sahip sağlık kurumları olma, atanmış 
statik yöneticilikten performans yönetimine geçilmesi, performans göstergeleri belirlenerek, performansa dayalı ödül sisteminin geliştirilmesi esasını benimsemektedir9.

\section{Gereç ve Yöntem}

\section{Araştırmanın Amacı}

Bu çalışma özel sektörde hizmet veren bir hastanedeki kariyer planlama ve geliştirme uygulamaları ile bu kurumda çalışan hemşirelerin kariyer planlama ve geliştirmeye ilişkin görüşlerinin belirlenmesi amacıyla planlanmıştır.

\section{Araştırma Yöntemi}

Araştırma, İstanbul ilinde bulunan özel bir hastanenin Avrupa ve Anadolu yakasındaki şubelerinde çalışan hemşirelerin kariyer planlama ve geliştirmeye ilişkin görüşlerinin belirlenmesi amacıyla tanımlayıcı olarak planlanmış ve Aralık 2008 - Şubat 2009 tarihleri arasında gerçekleştirilmiştir.

\section{Araştırmanın Evreni ve Örneklemi}

Araştırmanın evrenini iki aylık deneme süresini doldurmuş olan servis hemşiresi ve yönetici hemşire pozisyonunda görev yapan toplam 300 hemşire oluşturmuştur. Araştırmada örnekleme yöntemi kullanılmadan, evrenin tümüne ulaşılması hedeflenmiştir. Araştırmaya katılmayı kabul etmeyen, yıllık izin kullanan, özellikle yoğun bakım ve ameliyathane gibi kapalı birimler olmak üzere bazı birim hemşire ve yöneticilerine ulaşamama gibi nedenlerle araştırma evreninin tamamına ulaşılamamış ve sonuç olarak \%79 geri dönüş oranı sağlanarak, araştırmanın örneklemi 237 hemşireden oluşmuştur.

\section{Veri Toplama Araçları}

Araştırmanın verileri, araştırmacı tarafından literatür ışığında hazırlanan ve üç bölümden oluşan toplam 30 maddelik anket formu ile toplanmıştır.

Anket formunun birinci bölümünde; hemşirelerin kurumdaki görevi, yaşı, eğitim durumu, mesleki deneyimi, kurumdaki çalışma süresi ve mevcut pozisyonundaki çalışma yılını içeren 6 soru yer almaktadır.

Anket formunun ikinci bölümünde; kurumdaki kariyer planlama ve geliştirmeye yönelik uygulamaları içeren ve genel olarak kariyer planlama ve geliştirme 
uygulamalarını tanımlayan 15 soru yer almaktadır. 15 sorunun, beş tanesi birden fazla yanıtlı olmak üzere çoktan seçmeli ve iki tanesi açık uçlu sorulardan oluşmaktadır.

Üçüncü bölümde ise; hemşirelikte kariyer planlama ve geliştirme ile ilgili bireysel görüş ve önerilerini saptamaya yönelik 9 soru yer almaktadır. Bu 9 sorunun 2 tanesi birden fazla yanıtlı, bir tanesi sıralama sorusu (en çok 1, en az 6 olacak şekilde), iki tanesi açık uçlu ve 4 tanesi de çoktan seçmeli sorulardan oluşmaktadır.

\section{Araştırmanın Etik İzni}

Araştırmanın uygulanması için, Haliç Üniversitesi, Sağlık Bilimleri Enstitüsü Müdürlüğü’nden ilgili prosedürler sağlanarak yazılı olarak başvurulmuş, kurum sürecindeki Etik Kurul onayından sonra hastanelerin Başhekimlik ve Hemşirelik Hizmetleri Müdürlüğü’nden izin alınmıştır.

Araştırma kapsamına alınan tüm hemşirelere, araştırmanın amacı ve anketin doldurulma şekli ile Kariyer Planlama ve Geliştirme kavramı ve uygulamaları hakkında gerekli açıklamalar yapılarak hemşirelerin araştırmaya gönüllü katılımı sağlanmıştır.

\section{Verilerin Değerlendirilmesi}

Verilerin değerlendirilmesinde, araştırmadan elde edilen veriler bilgisayar ortamında SPSS (Statistical Program for Social Sciences) 12.0 programında analiz edilmiş, verilerin analizinde istatistiksel yöntem olarak, sayı ve yüzde; gruplar arasında yapılan karşılaştırmada ise, sayı, yüzde ve ki kare kullanılmıştır.

\section{Bulgular}

Araştırmada; hemşirelerin \%73'ü (n=173) servis hemşiresi; \%42,6’sı (n=101) 25 yaş altı; \%59,1’i ( $\mathrm{n}=140$ ) sağlık meslek lisesi mezunu, yaş ortalaması 26.93 26.08 yıl, ortalama çalışma süreleri $6.62 \pm 5.66 \mathrm{yll}$, kurumda çalışma süreleri $1.95 \pm 1.89$ yıl ve aynı pozisyonda çalışma süresi ise $3.82 \pm 3.55$ yıl olarak bulunmuştur (Tablo 1). 
Tablo 1: Hemşirelerin sosyo-demografik özelliklerinin dağılımı (n =237)

\begin{tabular}{|c|c|c|c|}
\hline & & $\mathbf{n}$ & $\%$ \\
\hline \multirow{2}{*}{ Pozisyon } & Yönetici Hemşire & 64 & 27,0 \\
\hline & Servis Hemşiresi & 173 & 73,0 \\
\hline \multirow{3}{*}{ Yaş } & $<25$ & 101 & 42,6 \\
\hline & $26-29$ & 67 & 28,3 \\
\hline & 30 ve üstü & 69 & 29,1 \\
\hline \multirow{4}{*}{ Eğitim } & Sağllk Meslek Lisesi & 140 & 59,1 \\
\hline & Önlisans & 27 & 11,4 \\
\hline & Lisans & 62 & 26,2 \\
\hline & Lisans Üstü & 8 & 3,4 \\
\hline \multirow{3}{*}{ Çalışma Süresi } & $0-5$ & 130 & 54,9 \\
\hline & $6-10$ & 63 & 26,6 \\
\hline & 11 ve üstü & 44 & 18,6 \\
\hline \multirow{3}{*}{ Kurumda çalışma süresi } & 2 ay -1 yll & 126 & 53,2 \\
\hline & 2-3 yll & 75 & 31,6 \\
\hline & 4 yıl ve üstü & 36 & 15,2 \\
\hline \multirow{3}{*}{ Pozisyonda çalışma süresi } & 2 ay -1 yll & 54 & 22,8 \\
\hline & $2-3$ yll & 87 & 36,7 \\
\hline & 4 yll ve üstü & 96 & 40,5 \\
\hline
\end{tabular}

Araştırmaya katılan hemşirelerden kurumlarında çalışanlara yönelik kariyer planlama ve geliştirme uygulaması olduğunu belirtenlerin oranı \%23,2 ( $n=55)$ uygulama olmadığını söyleyenlerin oranı \%50,2 (n=119) ve kısmen uygulama olduğunu belirtenlerin oranı ise \%26,6 $(n=63)$ olarak tespit edilmiştir (Tablo 2).

Servis hemşireleri, yönetici hemşirelere göre çalışanlara yönelik kariyer planlama ve geliştirme uygulamasının varlığına "evet” yanıtını verdiği saptanmış ve bu durum istatistiksel olarak anlamlı bulunmuştur ( $\mathrm{p}<0.05$ ) (Tablo 2).

Kurumda aynı pozisyonda çalışma süresi 2-3 yıl olanların diğer gruplara göre kurumlarında çalışanlara yönelik kariyer planlama ve geliştirme uygulamasının varlığına "hayır" yanıtı verdikleri belirlenmiş, bu durum istatistiksel olarak anlamlı bulunmuştur ( $\mathrm{p}<0.05)$ (Tablo 2). 
Tablo 2: Hemşirelerin kurumdaki kariyer planlama ve geliştirme uygulamasına ilişkin görüşlerinin sosyo demografik ve mesleki özelliklere göre dağılımı (n =237)

\begin{tabular}{|c|c|c|c|c|c|c|c|c|c|}
\hline \multicolumn{2}{|c|}{$\begin{array}{l}\text { Kariyer planlama ve } \\
\text { geliştirme uygulamasına } \\
\text { ilişkin görüşlerin dağılımı }\end{array}$} & \multicolumn{2}{|c|}{$\begin{array}{ll}\text { Evet } & \\
\text { n } & \%\end{array}$} & \multicolumn{2}{|c|}{ Hayır } & \multicolumn{2}{|c|}{ Kismen } & \multicolumn{2}{|c|}{ Ki-kare p } \\
\hline \multirow{2}{*}{ Pozisyon } & Yönetici Hemşire & 21 & 32,8 & 23 & 35,9 & 20 & 31,3 & \multirow{2}{*}{0,005} & \multirow{2}{*}{$0,021^{*}$} \\
\hline & Servis Hemşiresi & 98 & 56,6 & 40 & 23,1 & 35 & 20,2 & & \\
\hline \multirow{3}{*}{ Yaş } & $<25$ & 24 & 3,8 & 54 & 53,5 & 23 & 22,8 & \multirow{3}{*}{2,24} & \multirow{3}{*}{0,690} \\
\hline & $26-29$ & 13 & 19,4 & 34 & 50,7 & 20 & 29,9 & & \\
\hline & 30 ve üstü & 18 & 26,1 & 31 & 44,9 & 20 & 29,0 & & \\
\hline \multirow{3}{*}{ Eğitim } & $\begin{array}{l}\text { Sağlık Meslek } \\
\text { Lisesi }\end{array}$ & 34 & 24,3 & 68 & 48,6 & 38 & 27,1 & \multirow{3}{*}{0,83} & \multirow{3}{*}{0,933} \\
\hline & Önlisans & 7 & 25,9 & 13 & 48,1 & 7 & 25,9 & & \\
\hline & Lisans ve Üstü & 14 & 20,0 & 18 & 25,7 & 18 & 25,7 & & \\
\hline \multirow{3}{*}{$\begin{array}{l}\text { Çalışma } \\
\text { Süresi }\end{array}$} & O-5 yll & 31 & 23,8 & 73 & 56,2 & 26 & 20,0 & \multirow{3}{*}{8,89} & \multirow{3}{*}{0,064} \\
\hline & 6-10 yll & 11 & 17,5 & 29 & 46,0 & 23 & 36,5 & & \\
\hline & 11 yll ve üstü & 13 & 29,5 & 17 & 38,6 & 14 & 31,8 & & \\
\hline \multirow{3}{*}{$\begin{array}{l}\text { Kurumda } \\
\text { Çalışma } \\
\text { Süresi }\end{array}$} & 2 ay-1 yll & 24 & 19,0 & 66 & 52,4 & 36 & 28,6 & \multirow{3}{*}{11,21} & \multirow{3}{*}{$0,024^{*}$} \\
\hline & $2-3$ yil & 15 & 20,0 & 41 & 54,7 & 19 & 25,3 & & \\
\hline & 4 yll ve üstü & 16 & 44,4 & 12 & 33,3 & 8 & 22,2 & & \\
\hline \multirow{3}{*}{$\begin{array}{l}\text { Pozisyonda } \\
\text { Çalışma } \\
\text { Süresi }\end{array}$} & 2 ay-1 yıl & 16 & 29,6 & 19 & 35,2 & 19 & 35,2 & \multirow{3}{*}{10,54} & \multirow{3}{*}{$0,032^{*}$} \\
\hline & 2-3 yil & 19 & 21,8 & 53 & 60,9 & 15 & 17,2 & & \\
\hline & 4 yll ve üstü & 20 & 20,8 & 47 & 49,0 & 29 & 30,2 & & \\
\hline \multicolumn{2}{|l|}{ TOPLAM } & 55 & 23,2 & 119 & 50,2 & 63 & 26,6 & & \\
\hline
\end{tabular}

${ }^{*} \mathbf{p}<\mathbf{0 . 0 5}$

Kurumlarında çalışanlara yönelik kariyer planlama ve geliştirme sürecinin yazılı olduğunu belirten hemşirelerin oranı \%19,o $(n=45)$, yazılı olmadığını söyleyenlerin 
oranı \%64,6 (n=153) ve kısmen yazılı olduğunu belirtenlerin oranı ise \%16,4 (n=39) olarak bulunmuştur (Tablo 3).

Hemşirelerin \%25,3’ü $(\mathrm{n}=60)$ açı/boş pozisyonlara personel seçimi ve yerleştirilmesinde kurum içinden mevcut personelin kullanıldığı, \%16,5’i (n=39) kurum dışından personel temini sağlandığı ve $\% 58,2$ 'si $(n=138)$ ise her iki yöntemin birlikte uygulandığı belirlenmiştir.

Hemşirelerin \%30,8’i (n=73) kurum içerisindeki açlk/boş pozisyonlara personel seçiminde bireyin kariyer hedefinin dikkate alındığı, \%38,4’ü (n=91) dikkate alınmadığı ve \%30,8’i (n=73) kısmen dikkate alındığını, hemşirelerin \%25,7’si (n=61) kurumda görevde yükselme (terfi) prosedürünün olduğunu, \%57,4'ü (n=136) olmadığını ve \%16,9’u (n=40) kısmen olduğunu belirtmişlerdir (Tablo 3).

Tablo 3: Hemşirelerin kurumdaki kariyer planlama geliştirme uygulaması hakkındaki görüşlerinin dağılımı $(\mathrm{n}=237)$

\begin{tabular}{|c|c|c|c|c|c|c|}
\hline $\begin{array}{l}\text { Kariyer planlama geliştirme } \\
\text { uygulamalarına ilişkin ifadeler }\end{array}$ & Eve & $\%$ & Has & $\%$ & Kis & $\%$ \\
\hline $\begin{array}{l}\text { Hemşirelerin kurumdaki kariyer planlama } \\
\text { geliştirme sürecinin yazılı olma durumu }\end{array}$ & 45 & 19 & 153 & 64,6 & 39 & 16,4 \\
\hline $\begin{array}{l}\text { Kurumda görevde yükselme prosedürünün } \\
\text { olma durumu }\end{array}$ & 61 & 25,7 & 136 & 57,4 & 40 & 16,9 \\
\hline $\begin{array}{l}\text { Kurum içerisindeki açı/boş pozisyonlara } \\
\text { bireyin kariyer hedeflerinin dikkate alınma } \\
\text { durumu }\end{array}$ & 73 & 30,8 & 91 & 38,4 & 73 & 30,8 \\
\hline $\begin{array}{l}\text { Kariyer planlama ve geliştirmenin hemşirelik } \\
\text { mesleğine katkı durumu }\end{array}$ & 133 & 56,1 & 53 & 22,4 & 51 & 21,5 \\
\hline
\end{tabular}

Hemşirelerin \%34,2'si (n=81) kurum içerisinde açı/boş pozisyonlar ve gerekli nitelikler hakkında bilgilendirme yapıldığını, \%40,9'u (n=97) bilgilendirme yapılmadığını ve \%24,9’u (n=59) kısmen bilgilendirme yapıldığını belirtmişlerdir (Tablo 4). 
Kurumda çalışma süresi arttıkça bilgilendirme oranının da arttığı saptanmış, bu durum istatistiksel açıdan ileri derecede anlamlı bulunmuştur ( $\mathrm{p}<0.01)$ (Tablo 4).

Tablo 4: Hemşirelerin kurumlarında açı/boş pozisyonlar için gerekli nitelikler hakkında bilgilendirme durumlarının dağılımı ve karşılaştırılması (n=237)

\begin{tabular}{|c|c|c|c|c|c|c|c|c|c|}
\hline \multicolumn{2}{|c|}{$\begin{array}{l}\text { Açlk/boş pozisyonlar için } \\
\text { gerekli nitelikler hakkında } \\
\text { bilgilendirilme durumu }\end{array}$} & \multicolumn{2}{|c|}{$\begin{array}{ll}\text { Evet } & \\
\text { n } & \%\end{array}$} & $\begin{array}{l}\text { Ha } \\
\text { n }\end{array}$ & $\%$ & K1 & $\%$ & Ki-kare & $\mathbf{p}$ \\
\hline \multirow[b]{2}{*}{ Pozisyon } & Yönetici Hemşire & 25 & 39,1 & 19 & 29,7 & 20 & 31,3 & \multirow[b]{2}{*}{4,74} & \multirow[b]{2}{*}{0,093} \\
\hline & Servis Hemşiresi & 56 & 32,4 & 78 & 45,1 & 39 & 22,5 & & \\
\hline \multirow[b]{3}{*}{ Yaş } & $<25$ & 39 & 38,6 & 37 & 36,6 & 25 & 24,8 & \multirow{3}{*}{4,07} & \multirow{3}{*}{0,396} \\
\hline & $26-29$ & 23 & 34,3 & 31 & 46,3 & 13 & 19,4 & & \\
\hline & 30 ve üstü & 19 & 7,5 & 29 & 42,0 & 21 & 30,4 & & \\
\hline \multirow{3}{*}{ Eğitim } & $\begin{array}{l}\text { Sağlık Meslek } \\
\text { Lisesi }\end{array}$ & 59 & 42,1 & 49 & 35,0 & 32 & 22,9 & \multirow[t]{3}{*}{9,925} & \multirow[t]{3}{*}{,042* } \\
\hline & Önlisans & 6 & 22,2 & 13 & 48,1 & 8 & 29,6 & & \\
\hline & Lisans ve Üstü & 16 & 22,9 & 35 & 50,0 & 19 & 27,1 & & \\
\hline \multirow[b]{3}{*}{$\begin{array}{l}\text { Çalışma } \\
\text { Süresi }\end{array}$} & o-5 yil & 50 & 38,5 & 50 & 38,5 & 30 & 23,1 & \multirow{3}{*}{3,379} & \multirow{3}{*}{,496 } \\
\hline & 6-10 yll & 20 & 31,7 & 28 & 44,4 & 15 & 23,8 & & \\
\hline & 11 yll ve üstü & 11 & 25,0 & 19 & 43,2 & 14 & 31,8 & & \\
\hline \multirow{3}{*}{$\begin{array}{l}\text { Kurumda } \\
\text { Çalışma } \\
\text { Süresi }\end{array}$} & 2 ay-1 yll & 32 & 25,4 & 62 & 49,2 & 32 & 25,4 & \multirow{3}{*}{15,576} & \multirow{3}{*}{, $\mathbf{0 0 4}{ }^{* *}$} \\
\hline & 2-3 yll & 31 & 41,3 & 21 & 28,0 & 23 & 30,7 & & \\
\hline & 4 yll ve üstü & 18 & 50,0 & 14 & 38,9 & 4 & 11,1 & & \\
\hline \multirow{3}{*}{$\begin{array}{l}\text { Pozisyonda } \\
\text { Çalışma } \\
\text { Süresi }\end{array}$} & 2 ay-1 yl & 22 & 40,7 & 21 & 38,9 & 11 & 20,4 & \multirow{3}{*}{1,951} & \multirow{3}{*}{,745 } \\
\hline & 2-3 yll & 29 & 33,3 & 34 & 39,1 & 24 & 27,6 & & \\
\hline & 4 yll ve üstü & 30 & 31,3 & 42 & 43,8 & 24 & 25,0 & & \\
\hline \multicolumn{2}{|l|}{ TOPLAM } & 81 & 34,2 & 97 & 40,9 & 59 & 24,9 & & \\
\hline
\end{tabular}


Kurumda terfi ettirilmede dikkate alınan kriterler incelendiğinde hemşirelerin \%57,8’i $(n=137)$ eğitim düzeyinin, \%67,1’i $(n=159)$ yetenek ve performansın, \%56.5’i $(n=134)$ sorumlularının önerisinin, \%65,o’i (n=154) üst yönetimin önerisinin, \%17,7’si (n=42) çalışma arkadaşlarının önerisinin, \%19,4'̈̈ $(n=46)$ hasta memnuniyetinin ve \%11'nin $(n=26)$ diğer meslek üyelerinin önerisinin önemli olduğunu belirttikleri saptanmıştır (Tablo 5).

Hemşirelerin \%24,1’i (n=57) kurumda yapılan ilerleme ve terfilerde kurumun terfi politikasına çoğunlukla bağlı kalındığı, \%20,7’si (n=49) kesinlikle bağlı kalınmadığını ve \%55,3 ’ünün (n=131) ise kişiye ve pozisyona göre değiştiğini ifade etmişlerdir.

Tablo 5: Hemşirelerin bir üst pozisyona getirilmesinde dikkate alınan kriterlerin dağılımı $(n=237)$

\begin{tabular}{|l|lc|}
\hline $\begin{array}{l}\text { Çalışanların bir üst pozisyona getirilmesinde dikkate } \\
\text { alınan kriterler }\end{array}$ & $\mathbf{n}$ \\
\hline Ĕ̆itim Düzeyi & 137 & $\% 57,8$ \\
Yetenek ve Performans & 159 & $\% 67,1$ \\
Sorumluların Önerisi & 134 & $\% 56,5$ \\
Üst Yönetimin Önerisi & 154 & $\% 65,0$ \\
Çalışma Arkadaşları & 42 & $\% 17,7$ \\
Hasta Memnuniyeti & 46 & $\% 19,4$ \\
Diğer Meslek Üyelerinin Önerisi & 26 & $\% 11,0$ \\
\hline
\end{tabular}

\section{Katulmevlar birden fazla seçenek işaretlemişlerdir.}

Kurumda terfi ettirilmede dikkate alınan kriterler incelendiğinde hemşirelerin \%57,8’i ( $\mathrm{n=137)}$ (Tablo5) eğitim düzeyinin dikkate alındığını, hemşirelerin pozisyonlarına göre dağılımında; yönetici hemşirelerin \%81,3’ü $(n=52)$ yetenek ve performansa göre yapıldığını belirtmiş, bu durum istatistiksel olarak ileri derecede anlamlı bulunmuştur (p<0.01) (Tablo 6). 
Tablo 6: Hemşirelerin pozisyonları ile bir üst pozisyona getirilmesinde dikkate alınan kriterlerin karşılaştırılması $(\mathrm{n}=237)$

\begin{tabular}{|c|c|c|c|c|c|c|}
\hline \multirow{2}{*}{\begin{tabular}{|l|} 
Pozisyon \\
Çalışanların bir üst pozisyona \\
getirilmesinde dikkate alınan \\
kriterler
\end{tabular}} & \multicolumn{2}{|c|}{$\begin{array}{l}\text { Yönetici } \\
\text { Hemşire }\end{array}$} & \multicolumn{2}{|c|}{$\begin{array}{l}\text { Servis } \\
\text { Hemşiresi }\end{array}$} & & \\
\hline & & $\%$ & & $\%$ & \multicolumn{2}{|c|}{ Ki-kare $\quad$ p } \\
\hline Eğitim Düzeyi & 43 & 67,2 & 94 & 54,3 & 3,16 & 0,075 \\
\hline Yetenek ve Performans & 52 & 81,3 & 107 & 61,8 & 7,96 & $0,005^{* *}$ \\
\hline Sorumluların Önerisi & 43 & 67,2 & 91 & 52,6 & 4,04 & $0,044^{*}$ \\
\hline Üst Yönetimin Önerisi & 47 & 73,4 & 107 & 61,8 & 2,75 & 0,097 \\
\hline Çalışma Arkadaşları & 15 & 23,4 & 27 & 15,6 & 1,96 & 0,161 \\
\hline Hasta Memnuniyeti & 14 & 21,9 & 32 & 18,5 & 0,34 & 0,559 \\
\hline Diğer Meslek Üyelerinin Önerisi & 8 & 12,5 & 18 & 10,4 & 0,21 & 0,647 \\
\hline
\end{tabular}

${ }^{*} \mathrm{p}<0.05 \quad *{ }^{*} \mathrm{p}<0.01 \quad$ Kathlmcllar birden fazla seçenek işaretlemişlerdir.

Kurumda yüksek performansı olan hemşirelere yönelik uygulamalar incelendiğinde; hemşirelerin \%10,5’i (n=25) yüksek ücret ile ödüllendirme yapıldığını , \%19,8’i (n=47) terfi ettirildiğini, \% 7,2'si (n=17) ekstra prim verildiğini ve \%57’si (n=135) sözlü takdir ve diğer çalışanlara takdim edildiğini belirtmişlerdir.

Kurumda performansı az olan hemşirelere yönelik uygulamalar incelendiğinde hemşirelerin \%57,8’i (n=137) çalıştıkları birimin değiştirildiğini, \%42,6’sı (n=101) eğitim ve danışmanlık hizmetinin verildiğini, \%9,7'si $(n=23)$ terfi ettirilmediğini, \%29,5’i (n=70) yazılı uyarılarda bulunulduğunu, \% 4,6’sı (n=11) disiplin soruşturması açıldı̆̆ını ve \%28,7’si (n=68) işten çıkartıldı̆̆ını ifade etmişlerdir.

Kariyer planlama ve geliştirme hakkında kurumdan beklentiler incelendiğinde; hemşirelerin \%47,7'si (n=113) yönlendirme ve kariyer danışmanlığının yapılması, \%54,9'u (n=130) kariyer olanakları hakkında bilgilendirme yapılması ve \%58,2'si $(n=138)$ eğitim programlarının düzenlenmesi gerektiğini belirtmişlerdir. 
Hemşirelerin \%56,1’i (n=133) kariyer planlama ve geliştirmenin hemşirelik mesleğinin geliştirmesinde etkin bir yöntem olacağını, \%22,4’ü $(n=53)$ etkin bir yöntem olamayacağını ve \%21,5’i $(n=51)$ ise kısmen etkin olabileceğini düşündükleri belirtilmiştir.

Hemşirelerin hemşirelikte kariyer planlama ve geliştirme ile ilgili önerilerin dağılımına bakıldığında, \%38’i (n=90) mesleki gelişim sağlayacağını, \%26,6’sı (n=63) hemşirelik bakım kalitesinin artacağını, \%11’i $(n=26)$ iş doyumunda artış sağlanacağını ve \%24,4’ü $(n=58)$ mesleki prestijin artacağını düşündükleri ifade edilmiştir.

Hemşirelerin hemşirelikte kariyer planlama ve geliştirme ile ilgili olarak, \%38,3’ü ( $\mathrm{n}=91)$ sürekli eğitim programlarının hazırlanmasını, \%13,5’i $(\mathrm{n}=32)$ kurumdaki kariyer yolları hakkında bilgilendirme yapılmasını, \%12,2'si (n=29) hemşire sayısının arttırılmasını, \%9,2'si (n=22) performans değerlendirmenin adil yapılmasını, \%8,4'ü $(n=20)$ işe alma ve yerleştirmede eğitim ve uzmanlıkların dikkate alınmasını, \%8,8’i $(n=21)$ kariyer planlama ve geliştirme ile ilgili yazılı süreçlerin bulunmasını önermişlerdir.

\section{Tartışma}

Araştırmamıza katılan hemşireler, kurumlarında kariyer planlama ve geliştirme uygulamasının olmadığını ifade etmişler ve elde edilen bu sonuç, Sönmez (2007) ve Özçelik (2005)'in sonuçları ile paralellik göstermekte olup hastanelerde kariyer planlama ve geliştirmenin öneminin yeterince anlaşılmadığı düşünülmektedir3,10.

Özdemir (2004)'in çalışmasında, hemşirelerin kurum ile amaç birliği sağlanmadığı, kariyer planlama çalışmalarının etkin yapılmadığı, buna bağlı olarak hemşirelerin orta motivasyon düzeyinde oldukları saptanmıştır ${ }^{11}$.

Şahinöz (2006)'ün çalışmasında kurumun misyon, vizyon ve hedeflerini bilmek çalışanlara kariyer planlama ile ilgili yol gösterici olduğu belirtilmiştirir ${ }^{12}$.

Anafarta (2001)'nın çalışmasında; kariyer planlama ve geliştirmede kurumlara düşen görevler arasında, örgütteki kariyer basamaklarının ve faaliyetlerin net ve açık olarak belirtilmesi yer almaktadır².

Profesyonel organizasyonlardan biri olan Uluslararası Hemşireler Konseyi (ICN) 1995 yılında "Hemşireler için Kariyer Geliştirme" adlı bir çalışma yayımlamıştır. Bu 
çalışmada, hemşirelikte kariyer geliştirmenin; hem çalışma alanlarında hem de eğitim sisteminde, yöneticilerin ve profesyonellerin tutum ve uygulamaları tarafindan desteklenmesinin önemi vurgulanmıştır. ICN, hemşirelikte kariyer planlamaya yönelik tutarlı bir sistemin gerekliliğinin önemine dikkat çekmiştir ${ }^{13,14}$.

Araştırmamıza katılan hemşirelerin çoğu kurumda yazılı iş analizi ve görev tanımlarının olduğunu belirtilmiş ve bu sonuç Sönmez (2007)'in çalışma sonucu ile paralellik göstermiştir3. Kurumlarda iş analizi ve görev tanımlarının yazılı olarak var olması, örgüt içi kariyer yollarının oluşturulmasında ilk adımı oluşturmaktadır. Aynı zamanda, bireyin ilerleyeceği pozisyonlar için gerekli bilgi, beceri ve yeteneklerin ortaya çıkarılmasına yardımcı olması açısından da önemlidir ${ }^{1}$. Özel hastanelerde iş analizi ve görev tanımları kalite yönetimi sistemleri içerisinde var olmasına rağmen, 6283 sayılı Hemşirelik Kanunu'nda ve ilgili yönetmeliklerde tanımlanan hemşirenin görev, yetki ve sorumluluklarının uygulamadaki ihtiyaçları karşılayamaması, hemşirelik personelinin iş analizi ve görev tanımlarının etkinliğini azalttı̆̆ı söylenebilir.

Açlk/boş pozisyonlara personel seçimi ve yerleştirilmesinde, kurum içinden (iç kaynak) ve kurum dışından (dış kaynak) yeni iş gören alımının birlikte yapıldığı sonucuna ulaşılmıştır. Kurumlarda açık/boş pozisyonlara personel yerleştirmede iç kaynak kullanıldığında, kurumdaki kariyer planlama ve geliştirmenin varlığının önemi ve gerekliliği artmaktadır. Kurumlar bu durumda çalışanını ilgili pozisyon için gerekli bilgi, beceri ve yeteneğe sahip olması amacı ile yetiştirmek ve geliştirmek zorundadır.

Kurumda açık/boş pozisyonlar hakkında çalışan hemşirelere bilgilendirme yapılmadığı belirtilmiş, açı/boş pozisyonlara personel seçiminde bireyin kariyer hedeflerinin dikkate alınmadığı saptanmıştır. Örgütsel kariyer planlama ve geliştirmede kurumun en önemli sorunlarından biri, bireysel kariyer hedefleri ile örgütsel kariyer firsatlarını uyumlaştırmak, kurumdaki mevcut kariyer firsatlarından bireylerin haberdar olmalarını sağlamaktır²,3,15. Araştırmamızda elde edilen bulgu ise, açık pozisyonlar ve bu pozisyonlar için gerekli nitelikler hakkında bilgilendirilme açısından hastanelerin yetersiz olduğunu göstermektedir. Aynı zamanda bu durum, kurumda kariyer planlama ve geliştirme faaliyetlerinin tüm çalışanları kapsayacak şekilde kullanılmasını da engelleyeceği öngörülmektedir.

Kurumda çalışanların bir üst pozisyona getirilmesinde kişinin yetenek ve performansın dikkate alındığı belirlenmiş olup, Sönmez (2007)’in yapmış olduğu araştırma 
sonucunda ise, hemşire yöneticilerin bir üst pozisyona getirilmesinde üst yönetim kararının etkili olduğu görülmüştür. Birleşik Amerika Çalışma Departmanı’na göre 2015'e kadar emekliye ayrılan çok sayıda hemşirenin yerini dolduracak nitelikli hemşire işe alımları ortalamanın daha da üzerinde olacaktır. Buna göre, açık pozisyonlar ve işe alımların büyük çoğunluğu yönetim pozisyonlarında olacaktır, bu nedenle, hemşirelere ileriye yönelik olarak organizasyonun ve pozisyonun gereklerini karşılayacak önlemleri almaları önerilmektedir ${ }^{3,16}$.

Hemşirelerin kurumdaki çalışma süreleri ile bir üst pozisyona getirilme kriterleri incelendiğinde 4 yıl ve üstü süresince çalışanların "Eğitim Düzeyinin” dikkate alındığını belirtmiş, bu durum istatistiksel olarak anlamlı bulunmuştur ( $\mathrm{p}<0.05)$. Çalışma süresi arttıkça eğitimin öneminin daha çok anlaşılması ve terfilerde bireyin eğitim düzeyinin ön planda tutulması sonucu, hemşirelik mesleğinin gelişimi açısından olumlu bir sonuç olarak düşünülebilir.

Araştırmamızda performansı yüksek olan hemşirelere yapılan uygulamalar arasında “Terfi Ettirilmenin” olduğu yüksek oranda saptanmıştır. Öztürk ve Bahçecik (2005)’in hemşire ve yönetici hemşireler üzerine yaptıkları çalışmada, terfi etmenin onlar için önemli olduğu ve kurumlarında terfi ettirmenin genellikle illegal yapıldığını, yönetici hemşireler ve hemşirelerin terfi etme firsatı olmamasına rağmen daha fazla yetki ve sorumluluk verildiğinde öncelikle becerilerine güvenildiği, değerli oldukları ancak her iki grubunda bu durumunda istismar edildiği ve haksızlık yapıldığı belirtilmiştir ${ }^{17}$.

Araştırmamızda, kurumlarda yüksek performanslı hemşirelere yönelik teşvik edici uygulamalar arasında "Sözlü Takdir ve Takdim Etme” yüksek oranda bulunmuştur. Eroğlu (1995)'nun çalışmasında, bankalarda çalışanların verimini arttırmak için yapılan uygulamalar arasında sırayla terfi ettirme, sosyal yardımlar, teşvik edici prim sistemi ve eğitim yer almaktadır. Gözaydın (2002)’’n yapmış olduğu çalışmada ise, çalışanların daha etkin ve verimli çalışmaları için yapılan faaliyetler arasında en yüksek oranda kariyer planlamanın olduğu ve bunu teşvik edici prim sisteminin takip ettiği saptanmıştır ${ }^{18,19}$. Bireyin motivasyonu açısından sözlü takdir ve diğer çalışanlara takdim etme ile hemşirelik hizmetinde ki yüksek performansın ve bunun devamlılığının sağlanamayacağı düşünülmektedir. Etkin bir kariyer planlamasının bireylerin motivasyonu, ilerlemesi, kişisel gelişimi, iş tatmini üzerinde olumlu etkileri vardır ${ }^{20,21}$. Bireylerin bu planlamada gerçekçi hedefler belirlememeleri ise onların beklentilerinin 
ve stres düzeylerinin artmasına yol açacaktır. Bunun sonucunda bireyde işe karşı isteksizlik ve işe sebepsiz gelmeme durumları artacak, bazı durumlarda ise bireyde ruhsal bozukluklara sebep olabilecektir ${ }^{20,22}$.

Kurumda performansı az olan hemşirelere yönelik uygulamalar incelendiğinde hemşirelerin \%28.7'si (n=68) işten çıkartıldığını ifade etmişlerdir. Eroğlu (1995)'nun çalışmasında iş verimi düşen çalışanlara yönelik olarak ilk sırada, başarısızlık nedeninin araştırılması, Gözaydın (2002)'ın çalışmasında ise, ilk sırada sorunun nedenini araştırmak, ikinci sırada ise iş göreni uzman bir danışmanla görüştürmek yer almaktadır18,19. Kurumların mevcut çalışanlarını eğitmek, geliştirmek ve performanslarını arttırma çalışmaları yapmak yerine, yerlerine performansı yüksek yeni çalışan almak gibi sonuçlar ile sorunu çözmek istemeleri zaman açıdan daha iyi olacağı düşünülse bile her yeni çalışan alımının da bir risk olduğu düşünülmesi gereken önemli bir unsurdur.

Hemşirelerin kariyer planlama ve geliştirme ile ilgili kurumdan beklentilerinde ilk üç sırada, "Sürekli Eğitim Programlarının Düzenlenmesi”, "Kariyer Olanakları Hakkında Bilgi Sahibi Olma” ve "Yönlendirme, Kariyer Danışmanlığı” yer almaktadır. Acarbay (2006)'ın çalışmasında, kurumun "kariyer planlamanın kişisel gelişimi artırdığı" görüşünü desteklediği, ancak kurumda kariyer planlama çalışmaları olmadığı için, kişisel gelişimi artırmak, birey ve kurum amaçlarını birleştirmek ve dengede tutmak için eğitimler düzenledikleri belirtilmiştir ${ }^{16}$.

Kariyer planlama ve geliştirme hakkında iş görenlerin kurumdan beklentilerinin bilinmesi, beklentileri karşılayacak bir kariyer geliştirme sisteminin oluşturmasına yön verip etkinlik sağlamaktadır ${ }^{1}$.

Sönmez (2007)'in çalışmasında, hemşire yöneticilerin kariyer planlama ve geliştirme ile ilgili kurumdan beklentileri; "Kariyer Olanakları Hakkında Bilgi Sahibi Olma”, "Mesleğin Gerektirdiği Bilgiye Ulaşma”, "Yönlendirme ve Kariyer Danışmanlığı" ile "Kariyer Eşitliğì" olmuştur3. Bu sonuç, araştırma sonucumuz ile paralellik göstermektedir.

Literatürde; birey-örgüt bütünleşmesinin gerçekleşmesinde örgütlerde kariyer danışmanlığı önerilmektedir. Kariyer danışmanlığı yolu ile kariyerde ilerlemek ve 
başarılı olabilmek için gerek duyulan imkânlar sunularak, bireyin kariyer planlama ve geliştirme çalışmalarına yardımcı olunması üzerinde durulmaktadır.

Anafarta (2001)'nın yaptığı çalışmada, yöneticilerin işletmelerden en büyük beklentileri; koçluk ve danışmanlık hizmetlerinin verilmesi, örgütteki kariyer ilerleme olanakları hakkında bilgi sahibi olma, iş yapabilmek için yeterli bilgiye ulaşma ve kariyer eşitliğidir².

Hemşirelerin kariyer planlama ve uygulamaları ile elde etmeyi bekledikleri sonuçlar arasında yapılan sıralamada; “Çalışma Koşullarını İyileştirilmesi”, “Ücret Artışı”, “Uzun Süreli İstihdam”, "Yüksek Statü ve Prestij”, "Bireysel Gelişim ve Motivasyon”, "Güç ve Sorumluluk" şeklinde ifade edilmiştir. Ancak, kariyer planlama ve geliştirme sonucunda bireysel ve mesleki gelişim, uzmanlaşma ve çalışanların alanında uzman olarak daha fazla güç ve sorumluluk kazanması beklenmektedir ${ }^{4}$. Araştırmamızda ise “Güç ve Sorumluluk” ve "Bireysel Gelişim ve Motivasyon” hemşirelerin uygulamalardan beklentileri arasında daha alt sıralarda yer almaktadır.

Türkiye'de sağlık hizmetinin, hemşire/hasta oranının yüksek verildiği ve uygun olmayan çalışma koşulları altında bireysel ve mesleki gelişimini tamamlamayan hemşirelerin istenilen performansı gösteremeyeceği söylenebilir. Bununla birlikte, yapılan iş ile karşılığında alınan ücret arasındaki dengesizliğin hemşirelerin motivasyonu ve mesleki gelişime dair bakışını olumsuz etkilediği düşünüldüğünde, elde edilen bulguların ülkemiz koşullarını yansıttığı görülmektedir.

Hemşirelikte kariyer planlama ve geliştirmenin hemşirelik için etkin bir yöntem olma durumu sorulduğunda, etkin bir yöntem olabileceğini belirttikleri saptanmıştır. Mutlu (2010)'nun çalışmasında, hemşireler kariyer planlama çalışmaları ile yeniliklere daha iyi uyum sağladıklarını belirtmişlerdir²3.

Nitelikli bir hemşirelik hizmeti verebilmek için, sürekli kendini geliştiren ve yenileyen bir meslek grubunun oluşması gerekmektedir. Bu durumda hemşirelerin kariyer planlama ve geliştirmenin hemşirelik mesleği için yararlı olacağına dair çoğunlukla olumlu bir bakış açısına sahip olunduğu görülmektedir.

Kariyer planlama ve geliştirmenin hemşirelik mesleğine katkıları ile ilgili görüşler incelendiğinde; "Mesleki Gelişim”, "Hemşirelik Bakım Kalitesinin Artması” ilk iki sırada olduğu belirlenmiştir. Elde edilen bu bulgu bireysel ve örgütsel kariyer planlama 
ve geliştirmenin yararları ile benzerlik göstermesi bakımından önemli bulunmaktadır. $\mathrm{Bu}$ durum, kariyer planlama ve geliştirme ile bireyin geliştirilmesinden yola çıkılarak, örgütsel amaçlara ulaşabileceğini göstermektedir. Ancak, bireyin geliştirilmesi tek başına yeterli olmadığı, yetki ve sorumluluk artışı, ücret artışı, ödüllendirme ile devamlılı̆̆ın sağlanması ve kazanılan yeteneğin kullanılması için desteklenmesi gerektiği düşünülmektedir.

Mesleğine katkıları ile ilgili görüşlerde; “Bireysel Kariyerlerini Planlamaları İçin Teşvik Edilmesi" "Performans Değerlendirmenin Adil Yapılması” önerilmektedir. Bu durum, hemşirelerin bireysel kariyerlerini planlamalarında yönetim tarafından teşvik edilmediklerini ayrıca kariyer planlama ve geliştirme uygulamalarında çok önemli role sahip olan, performans değerlendirmelerinin uygun yapılmadığını düşündürmektedir. Kariyer planlama ve geliştirme uygulamalarında kurum bireyleri kariyerleri için eğitmeli ve destek sağlamalıdır ${ }^{1}$.

Çalışmada, "Hemşire Sayısının Arttırılmasını" da önerilen maddeler arasında yer almaktadır. Hemşire yetersizliği, sağlıklı istihdamı etkilemekte ve hemşirelerin yetenekleri ve uzmanlık alanları ile farklı birimlerde çalıştırılmalarına neden olmaktadır. Ülkemizde hemşire yetersizliği söz konusu olmakla birlikte, hemşirelerin hemşirelik işlevi ile ilgili olmayan birimlerde çalıştırılmaları da sağlıksız istihdama neden olmaktadır. Hemşire sayısı, hemşire/hasta oranını etkileyerek, hemşirelerin bilgi ve yeteneklerini kullanabilecek çalışma ortamı sağlayarak hizmetin kalitesini arttıracaktır. Amerika Birleşik Devletleri’ndeki hemşire ve hekim sayıları yeterli olan “mıknatıs (magnet) hastaneler" olarak adlandırılan hastanelerin, cazip çalışma ortamlarının, gelişim ve ilerleme fırsatlarının, personel işe alımı ile mevcut personelin elde tutulmasına katkı sağladığı belirtilmektedir ${ }^{10}$. Hemşirelerin sağlıklı istihdamının, kariyer planlama ve kariyer geliştirme uygulamalarının başarısında etkili olacağı düşünülmektedir.

\section{Sonuç}

Çalışmada, kurumda kariyer planlama ve geliştirme uygulaması, yazılı kariyer planlama ve geliştirme sürecinin başka bir deyişle kariyer politikasının bulunmadığı ve kariyer planlama ve geliştirme hakkında kurumda çalışanların yeterince bilgilendirilmediği sonucuna ulaşılmıştır. 


\section{Öneriler}

- Hastane yönetim politikalarında kariyer planlama ve kariyer geliştirmenin önemi ile bireye ve kuruma olan katkılarına yer verilmeli ve bu politikalar doğrultusunda kariyer planlama geliştirme uygulama süreci oluşturulmalıdır.

- Kariyer planlama konusunda eğitim programları geliştirilmeli ve personelin bundan adil bir şekilde yararlanması sağlanarak terfi ve yükselmelerde informal ilişkiler önlenmelidir.

- Hemşirelerin çalıştıkları birimler ile kariyer hedeflerine uygun eğitim almaları sağlanmalı ve hemşirelerin bireysel ve mesleki gelişimlerine yönelik yapılandırılmış eğitim programları uygulanmalıdır.

\section{KAYNAKLAR}

1. Aytaç S. Çalışma Yaşamında Kariyer Yönetimi Planlaması Gelişimi ve Sorunlar. Bursa: Ezgi Kitabevi; 2005.

2. Anafarta N. Orta düzey yöneticilerin kariye planlamasına bireysel perspektif. Akdeniz Üniversitesi İktisadi ve İdari Bilimler Fakültesi Dergisi. 2001;2(1):17.

3. Sönmez B. Sağlık Kuruluşlarında Kariyer Planlama ve Geliştirme Uygulamalarına İlişkin Hemşire Yöneticilerin Görüşlerinin Belirlenmesi. [yüksek lisans tezi]. İstanbul, Türkiye: Hemşirelikte Yönetim Anabilim Dalı, İstanbul Üniversitesi Sağllk Bilimleri Enstitüsü; 2007.

4. Erdoğmuş N. Kariyer Geliştirme Kuram ve Uygulama. Ankara: Nobel Yayın; 2003.

5. Donner GJ, Wheeler M. Career planning and development for nurses: The time has come. International Nursing Review. 2001;48(2):79-85.

6. Edmonstone J, Whatt S. Career management suppoit for nurses. Health Monpower Management. 1995;6:21-19.

7. TC Sağlık Bakanlığı. Sağlık Bakanlığı Hizmet İçi Eğitim Yönetmeliği. http://www.resmigazete.gov.tr/eskiler/2004/01/20040111.htm. Erişim tarihi o3 Mayıs 2018. 
8. Hemşirelik Kanununda Değişiiklik Yapılmasına Dair Kanun. http://www.resmigazete.gov.tr/eskiler/2007/05/20070502-3.htm. Erişim tarihi o3 Mayıs 2018.

9. Hastane İnsan Kaynakları 360 Derece Performans Değerlendirme Projesi. İnsan Kaynakları ve Yönetim Dergisi. 2005;10:21.

10. Özçelik M. Yönetici Hemşirelerin Hemşirelere Yönelik Kariyer Planlama Faaliyetlerinin Belirlenmesi. [yüksek lisans tezi]. İstanbul, Türkiye: Marmara Üniversitesi Sağlık Bilimleri Enstitüsü; 2005.

11. Özdemir E. Hemşirelerin Motivasyon Düzeyleri. [yüksek lisans tezi]. İstanbul, Türkiye: Hemşirelikte Yönetim Anabilim Dalı, Marmara Üniversitesi Sağlık Bilimleri Enstitüsü; 2004.

12. Şahinöz Ş. Kurum Kültürünün Oluşumunda Kariyer Yönetiminin Yeri ve Bir Uygulama. [yüksek lisans tezi]. İstanbul, Türkiye: İşletme Anabilim Dalı, Yıldız Teknik Üniversitesi Sosyal Bilimler Enstitüsü; 2006.

13. Göz F, Gürbüz K. Hemşirelikte kariyerinizi keşfedin. Atatürk Üniversitesi Hemşirelik Yüksekokulu Dergisi. 2005;8(2):82-87.

14. Bektemür G, Demiray S, Ürkmez D. Hemşirelerin kariyer planlaması: Bir eğitim ve araştırma hastanesi örneği. Okmeydanı Tip Dergisi. 2016;32(1):7-13.

15. Freed PE, Dowson S. Is nursing management in your future? Nursing Management. 2006;37(10):43-48.

16. Acarbay B. Kariyer Planlamada Eğitim Etkinliklerinin Önemi. [yüksek lisans tezi]. İstanbul, Türkiye: Marmara Üniversitesi Sosyal Bilimler Enstitüsü; 2006.

17. Öztürk H, Bahçecik N. Bir kamu hastanesinde çalışan hemşirelerin iş zenginleştirme ve motivasyonuna yaklaşımları. In: III. Ulusal Sağlık Kuruluşları Yönetimi Kongresi; 17 Mart 2005; İstanbul, Türkiye.

18. Gözaydın AK. İşletmelerde Kariyer Planlaması Olgusu ve Kariyer Planlaması Konusunda Bankacılık Sektöründe Yapılan Bir Araştırma. [yüksek lisans tezi]. İstanbul, Türkiye: İstanbul Üniversitesi Sosyal Bilimler Enstitüsü; 2002. 
19. Eroğlu LB. Kariyer Planlaması ve Uygulamadan Örnekler. [yüksek lisans tezi]. İstanbul, Türkiye: Yönetim ve Organizasyon Anabilim Dalı, Marmara Üniversitesi Sosyal Bilimler Enstitüsü; 1995.

20. Seçer H. Bireysel Kariyer Planlama ve Kişisel Başarı Algısı Arasındaki İlişki ve Pamukkale Üniversitesi’nde Bir Araştırma. [yüksek lisans tezi]. Denizli, Türkiye: Pamukkale Üniversitesi Sosyal Bilimler Enstitüsü; 2013.

21. Tunçer P. Değişen insan kaynakları yönetimi anlayışında kariyer yönetimi. Ondokuz Mayıs Üniversitesi Eğitim Fakültesi Dergisi. 2012;31(1):203-233.

22. Varol ES. Kariyer yönetimi, planlaması ve yeni gelişmeler. İşletme İktisadi Enstitüsü Dergisi. 2001;12:17-27.

23. Mutlu A. Hemşirelerin Kariyer Planlamasına İlişkin Görüşlerinin Belirlenmesi. [yüksek lisans tezi]. İstanbul, Türkiye: Hemşirelikte Yönetim Anabilim Dalı, Marmara Üniversitesi Hemşirelikte Yönetim Anabilim Dalı; 2010. 